\title{
UJI KUALITAS AIR SUMUR GALI DI JALAN ANDI TONRO MAKASSAR
}

\author{
Anita ${ }^{1)}$, Hasnah ${ }^{1)}$, Effendy Rasiyanto ${ }^{1)}$ \\ ${ }^{(1}$ Akademi Analis Kesehatan Muhammadiyah Makassar \\ Alamat Korespondensi: nita_uh@yahoo.co.id
}

\begin{abstract}
Abstrak
Sumur gali merupakan salah satu sumber penyedia air bersih bagi masyarakat, yang berasal dari lapisan tanah oleh karena itu mudah terkena kontaminasi melalui rembesan yang berasal dari kotoran manusia, hewan maupun dari limbah domestik rumah tangga. Penelitian ini dilatar belakangi oleh masih kurangnya kesadaran masyarakat akan pentingnya kebersihan yang dapat menimbulkan berbagai penyakit yang salah satu sumbernya adalah air sumur gali yang tercemar oleh bakteri. Penelitian ini bertujuan untuk menemukan adanya kontaminasi Salmonella typhi, pada 6 sampel air sumur gali di jalan Andi Tonro yang bersifat observasi laboratorik. Berdasarkan hasil penelitian yang dilakukan diperoleh hasil pada media SSA didapatkan 3 sampel yang positif yaitu kode sampel B, C, E dan pada media identifikasi tidak ditemukan bakteri Salmonella typhi, tetapi ditemukan adanya bakteri Escherichia coli. Dari penelitian ini disarankan kepada masyarakat agar lebih mengantisipasi penularan penyakit, dengan meningkatkan kebersihan diri dan lingkungan.
\end{abstract}

Kata Kunci: Escherichia coli, Salmonella typhi, Sumur Gali

\section{PENDAHULUAN}

Air merupakan kebutuhan pokok dalam kehidupan manusia. Air dapat membuat orang menjadi sehat tetapi juga berpotensi sebagai media penularan penyakit. Air bersih adalah air yang jernih, tidak berwarna, dan tidak berbau. Melalui penyediaan air bersih dan sebagai pemenuhan kebutuhan sehari-hari, masyarakat melakukan usaha dengan swadaya masyarakat sendiri yaitu dengan membuat sumur gali. Kemampuan penyediaan air bersih untuk kehidupan sehari-hari bagi manusia adalah hal yang sangat penting (Purbowarsito, 2011).

Sumur gali merupakan salah satu sumber penyediaan air bersih bagi masyarakat di pedesaan maupun perkotaan. Sumur gali menyediakan air yang berasal dari lapisan tanah yang relatif dekat dengan permukaan tanah, oleh karena itu mudah terkena kontaminasi melalui rembesan yang berasal dari kotoran manusia, hewan, maupun untuk keperluan domestik rumah tangga (Angela, et.al, 2011).

Masalah utama yang dihadapi oleh sumber daya air di Indonesia meliputi kuantitas air yang sudah tidak mampu memenuhi kebutuhan yang terus meningkat dan kualitas air untuk keperluan domestik yang semakin menurun. Kegiatan industri, domestik dan kegiatan lain berdampak negatif terhadap sumber daya air, antara lain menyebabkan penurunan kualitas air. Kondisi ini dapat menimbulkan gangguan, kerusakan dan berbahaya bagi semua makhluk hidup yang tergantung pada sumber daya air (Radji et al, 2008).

Salmonella typhi merupakan salah satu penyakit endemis dan menimbulkan kerugian yang serius terutama di negara berkembang termasuk Indonesia. Bakteri Salmonella typhi ditularkan melalui makanan dan minuman yang terkontaminasi kotoran tinja atau tinja dari seseorang penderita tifoid. (Aryani, 2006).

Air sumur gali di jalan Andi Tonro Makassar merupakan sumber air bagi masyarakat yang tinggal di wilayah tersebut air sumur galian ini juga dijadikan alternatif bagi masyarakat dalam melakukan aktifitasnya sehari-hari, baik itu digunakan untuk mandi, mencuci bahkan digunakan untuk memasak maka dari itu perlu dilakukan pemeriksaan 
untuk mendeteksi keberadaan bakteri Salmonella typhi pada air sumur gali. Oleh karena itulah penelitian ini dilakukan untuk mengidentifikasi adanya bakteri Salmonella typhi pada air sumur gali dijalan Andi Tonro Makassar.

\section{METODE PENELITIAN}

Alat dan Bahan

Alata yang digunakan adalah tabung reaksi, rak tabung reaksi, Erlenmeyer, gelas kimia, tabung reaksi, cawan porselin, batang pengaduk, autoclave, Mikroskop, inkubator, Bak pewarnaan, pipet tetes, kapas, objek gelas, lampu spiritus, ose, nal.

Bahan yang digunakan adalah sampel air sumur gali dengan kedalaman rata-rata sumur 7-10 meter, Media BHIB, SSA, SIM, SCA, TSIA, MR-VP, gulagula (glukosa, laktosa, maltosa,sukrosa, mannitol), lugol, dan alkohol $96 \%$, carbon gention violet (CGV) dan fuchsin.

\section{Prosedur Penelitian}

\section{Preparasi Sambil}

Sampel air sumur gali diperoleh dengan menggunakan botol yang diikat tali dan ditutunkan perlahan-lahan ke dalam sumur. Setelah botol penuh air, ditarik perlahan-lahan, jangan sampai menyentuh dinding sumur, airnya dibuang sedikit kemudian ditutup kembali dengan penutupnya secara steril (Nurwana, 2010).

\section{Kultur Sampel}

Sampel air sumur gali ditanam pada media BHIB dan diinkubasi pada suhu $37^{\circ} \mathrm{C}$ selama 24 jam. Koloni yang tumbuh pada media BHIB diambil kemudian ditanam pada media SSA lalu diinkubasi pada suhu $37^{\circ} \mathrm{C}$ selama 24 jam. Koloni yang tumbuh pada media SSA diambil lalu dilakukan pewarnaan gram. Kemudian koloni yang berasal dari media SSA diambil kemudian ditanam pada media identifikasi yaitu media gula-gula (glukosa, sukrosa, maltosa, laktosa, mannitol), media SIM, SCA, MR-VP. Selanjutnya diinkubasi pada suhu $37^{\circ} \mathrm{C}$ selama 24 jam. Dilakukan pembacaan hasil pada media TSIA, SIM, MR-VP dan media gula-gula, hasil pembacaan tersebut dicatat kemudian dicocokkan dengan ciri-ciri sifat bakteri Salmonella typhi.

\section{HASIL PENELITIAN}

Sampel air sumur gali yang diperoleh dari sumur gali di jalan Andi Tonro Makassar dibawa ke laboratorium Bakteriologi untuk dilakukan pemeriksaan melalui metode kultur. Hasil penelitian ditunjukkan pada tabel 1

berikut:

Tabel 1. Hasil Uji Kualitas Air Sumur Gali Di Jalan Andi Tonro Makassar

\begin{tabular}{|c|c|}
\hline $\begin{array}{c}\text { Kode } \\
\text { Sampel }\end{array}$ & $\begin{array}{l}\text { Hasil Kultur Bakteri pada } \\
\text { Sampel Air Sumur Gali }\end{array}$ \\
\hline A & $\begin{array}{l}\text { Tidak Ditemukan adanya Bakteri } \\
\text { Salmonella typhi dan Bakteri } \\
\text { Escherichia coli }\end{array}$ \\
\hline B & $\begin{array}{l}\text { Tidak ditemukan adanya Bakteri } \\
\text { Salmonella typhi namun namun } \\
\text { ditemukan adanya Bakteri } \\
\text { Escherichia coli } \\
\text { Tidak ditemukan adanya Bakteri }\end{array}$ \\
\hline $\mathrm{C}$ & $\begin{array}{l}\text { Salmonella typhi namun ditemukan } \\
\text { adanya Bakteri Escherichia coli } \\
\text { Tidak ditemukan adanya Bakteri }\end{array}$ \\
\hline D & $\begin{array}{l}\text { Salmonella typhi dan Bakteri } \\
\text { Escherichia coli } \\
\text { Tidak ditemukan adanya Bakteri }\end{array}$ \\
\hline $\mathrm{E}$ & $\begin{array}{l}\text { Salmonella typhi namun ditemukan } \\
\text { adanya Bakteri Escherichia coli } \\
\text { Tidak ditemukan adanya Bakteri }\end{array}$ \\
\hline $\mathrm{F}$ & $\begin{array}{l}\text { Salmonella typhi dan Bakteri } \\
\text { Escherichia coli }\end{array}$ \\
\hline
\end{tabular}

\section{PEMBAHASAN}

Salmonella typhi merupakan salah satu spesies bakteri Salmonella yang berbentuk basil, gram negatif, fakultatif aerob, bergerak dengan flagel pertrich. Bakteri Salmonella typhi ditularkan melalui makanan dan minuman yang terkontaminasi kotoran tinja atau tinja dari seseorang penderita tifoid.

Sampel yang digunakan pada penelitian ini adalah air sumur gali di jalan Andi Tonro Makassar. Tahapan pengambilan sampel air sumur gali di jalan andi tonro peneliti menggunakan botol yang disterilkan terlebih dahulu di laboratorium sebelum pengambilan sampel, setelah disterilkan botol tersebut diletakkan didalam kotak sampel kemudian dibawa ke lokasi penelitian 
untuk pengambilan air sumur gali yang akan diteliti, teknik pengambilan sampel yang digunakan pada penelitian ini adalah random sampling, sampel yang diambil yaitu sebanyak 6 sampel.

Pengambilan sampel dilakukan dengan cara pada sampel kode A yaitu sumurnya mempunyai jarak 18 meter dari kanal dan jarak dari sumur dan wc berjarak 1 meter dengan pembuangan wc nya dari sumur jauh dengan kedalaman 7 meter. Pada sampel kode B yaitu sumurnya mempunyai jarak 15 meter dari kanal dan jarak dari sampel kode A sejauh 10 meter dan jarak dari sumur ke wc sejauh 1,5 meter dengan pembuangan langsung kebawah dengan kedalaman \pm 6 meter. Pada sampel kode $\mathrm{C}$ yaitu sumurnya mempunyai jarak 16 meter dari kanal dan jarak dari sampel kode B sejauh 6 meter sedangkan jarak dari sumur ke wc sejauh 2 meter dengan pembuangan langsung kebawah dengan kedalaman \pm 8 meter. Pada sampel kode D yaitu sumurnya mempunyai jarak 10 meter dari kanal dan jarak dari sampel kode $\mathrm{C}$ sejauh 5 meter dan jarak dari sumur ke wc sejauh 3,5 meter dengan pembuangan langsung dari kanal. Pada sampel kode E mempunyai jarak 6 meter dari kanal dan jarak dari sampel kode D sejauh 5 meter dan jarak dari sumur ke wc sejauh 1 meter dengan pembuangan wcnya langsung kebawah dengan kedalaman 9,5 meter, sedangkan pada sampel kode $F$ mempunyai jarak sejauh 20 meter dari kanal dan jarak dari sampel kode E sejauh 15 meter sedangkan jarak dari sumur ke wc sejauh 5 meter dengan pembuangannya wc dari sumur jauh \pm 10 meter.

Pada proses identifikasi Bakteri Salmonella typhi dari 6 sampel Air sumur Gali pertama-tama yang dilakukan yaitu sampel air sumur ditanam pada media BHIB pada suhu $37^{0} \mathrm{C}$ selama 24 jam. Pembacaan dilakukan setelah 24 jam dengan melihat adanya kekeruhan pada tabung, kemudian diambil lalu ditanam pada media SSA pada suhu $37^{\circ} \mathrm{C}$ selama 24 jam kemudian diamati koloni yang tumbuh pada media SSA. Kemudian koloni yang tumbuh dari media SSA selama 24 jam dengan melihat adanya pertumbuhan koloni tersangka terlihat berwarna bening, kecil, bulat.

Setelah itu dilanjutkan dengan pewarnaan gram yang digunakan untuk menentukan kelompok bakteri gram negatif (merah) atau gram positif (ungu) secara mikroskopik, pada pewarnaan ini digunakan Carbon Gention Violet (CGV) sebagai zat warna pertama, lugol sebagai penguat gram (+) atau gram (-), alkohol sebagai larutan peluntur dan fuchsin sebagai zat warna kedua. Kemudian dari media SSA ini hanya beberapa sampel yang positif yaitu sampel kode B, sampel kode $\mathrm{C}$ dan sampel kode $\mathrm{E}$, setelah itu koloni dari media SSA diambil lalu ditanam pada media identifikasi seperti media TSIA, SIM, SCA, MR-VP dan media gula-gula (glukosa, maltosa, laktosa, sukrosa, mannitol). kemudian dilakukan pembacaan hasil setelah 24 jam.

Berdasarkan Tabel 1. Hasil penelitian keenam sampel air sumur gali yang diuji ditemukan adanya Bakteri Escherichia coli, hal ini disebabkan karena letak sumur gali berdekatan dengan kanal dan pembuangan wc sehingga sampel air sumur gali tercemar oleh bakteri Escherichia coli. Sedangkan bakteri Salmonella typhi tidak ditemukan, karena tidak semua masyarakat sekitar yg menggunakan air sumur gali menderita penyakit demam tifoid

\section{KESIMPULAN}

Berdasarkan hasil penelitian tentang uji kualitas Air Sumur Gali di jalan Andi Tonro Makassar yang dilakukan di laboratorium Bakteriologi Analis Kesehatan Muhammadiyah Makassar, tidak ditemukan adanya Bakteri Salmonella typhi akan tetapi tercemar oleh bakteri Escherichia coli.

\section{DAFTAR PUSTAKA.}

Aryani. 2006. Pengaruh Pemberian

Ekstrak Umbi Gynura Procumbens

Terhadap Jumlah Kuman Kultur

Hepar Pada Mencit Balb/C Yang

Diinfeksi Salmonella typhimurium.

Semarang.

Ardiansyah. 2012. Faktor-faktor Yang

Berhubungan Dengan Kualitas 
Bakteriologis Air Sumur Gali Didesa Tensaren Kecamatan Bebesen Kabupaten Aceh Tengah.

Angela et al. 2011. Gambaran Kondisi Fisik Sumur Gali Di Tinjau Dari Aspek Kesehatan Lingkungan Dan Perilaku Pengguna Sumur Gali Di Kabupaten Summopo Kecamatan Tuminting Kota Manado (Skripsi). Manado: Fakultas Kesehatan Masyarakat Universitas Sam Ratulangi Manado.

Anugrah. 2013. Identifikasi Coliform Pada Air Sumur Gali Masyarakat Di Kota Makassar. Makassar: Akademi Analis Kesehatan Muhammadiyah Makassar.

Darmawati. 2009. Keanekaragaman Genetik Salmonella Typhi, Analis Kesehatan Fikkes Unimus.

Fardin et al. 2011. Isolasi dan Identifikasi Bakteri, Makassar.

Fakhrurroja 2010. Membuat Sumur Air Diberbagai Lahan, Jakarta.

Jawetz. 2006. Salmonella typhi. http://wisuda.unud.ac.id/pdf/12922 61003-3-Bab\%202.pdf..

Radji et al. 2008. Pemeriksaan Bakteriologis Air Minum Isi Ulang Di Beberapa Depo Air Minum Isi ulang Di Daerah Lenteng Dan Srengseng Sawah Jakarta Selatan, Depok.

Suryana. 2013. Analis Kualitas Air Sumur Dangkal Dikecamatan Biringkanaya kota Makassar, Fakultas Teknik Universitas Hasanuddin Makassar.

Trisna. 2014. Kualitas Dan Kuantitas Air Bersih Untuk Pemenuhan Kebutuhan.

http//id.scribd.com/doc/228035774.

Putra. 2010. Analisa Kualitas Fisik, Bakterioogis Dan Kimia Air Sumur Gali Serta Gambaran Keadaan Konstruksi Sumur Gali Di Desa Patumbak Kampung Kecamatan Patumbak Kabupaten Deli Serdang, Fakultas Kesehatan Masyarakat Universitas Sumatera Utara Medan.
Purbowarsito. 2011. Uji Bakteriologis Air Sumur Dikecamatan Semampir Surabaya. Departemen Biologi Fakultas Sains dan Teknologi Universitas Airlangga, Surabaya.

Nurwana. 2010. Identifikasi Escherichia coli pada Air Sumur Gali di Desa Bontoramba Kecamatan Palangga Kabupaten Gowa (KTI). Makassar: Akademi Analis Kesehatan Muhammadiyah Makassar. 